DOI: https://doi.org/10.47631/jareas.v2i3.323

\title{
The Impact of Participative Decision-Making on Organizational Commitment: A Study among Employees of Mobile Telecom Companies in Yemen
}

\author{
Salah Naji Taher Sanad ${ }^{1}$, Dr. Anitha.S ${ }^{2}$ \\ ${ }^{I}$ Ph.D. Research Scholar in Management Studies, University of Kerala, Trivandrum, India. \\ ${ }^{2}$ Assistant Professor, Department of Personnel Management, Loyola College of Social Sciences, \\ University of Kerala, Trivandrum, India.
}

\begin{tabular}{|c|c|}
\hline Article Info & Abstract \\
\hline Article history: & Purpose: The study aimed at examining the relationship between participative \\
\hline :21 June 2021 & decision-making and organizational commitment among employees working \\
\hline Revi & in mobile telecom companies in Yemen. \\
\hline Acce & $\begin{array}{l}\text { Approach/Methodology/Design: This study is descriptive-analytical. The } \\
\text { study population comprised the employees working at the four mobile telecom }\end{array}$ \\
\hline Keywords: & $\begin{array}{l}\text { companies in Sana'a, Yemen's capital city (Yemen Mobile, Sabafon, MTN and } \\
\text { Y-Telecom). One hundred twenty questionnaires were collected and were }\end{array}$ \\
\hline Participative Decision & valid for the data analysis. Different statistical tools, including regression \\
\hline Making, Employee & analysis and correlation coefficients, were applied, and data were analyzed \\
\hline Engagement, Organizational & using SPSS. \\
\hline Commitment, Telecom & Findings: The regression analysis output shows a significant positive \\
\hline Companies, Yemen & $\begin{array}{l}\text { relationship between participative decision-making and affective commitment } \\
(\beta=0.48, p<0.001) \text {. Furthermore, the regression analysis shows a }\end{array}$ \\
\hline M15, M20 & significant positive relationship between participative decision making and \\
\hline Type : & continuance commitment $(\beta=0.59, p<0.001)$. In addition, the significance \\
\hline Research Article & $\begin{array}{l}\text { of regression analysis tested using the regression coefficients shows a } \\
\text { significant positive relationship between participative decision-making and }\end{array}$ \\
\hline Corresponding Author: & $\begin{array}{l}\text { normative commitment }(\beta=0.72, p<0.001) \text {. } \\
\text { Practical Implications: The study recommends that the companies managers }\end{array}$ \\
\hline Salah Naji Taher Sanad & $\begin{array}{l}\text { need to motivate and inspire their employees to actively participate in the } \\
\text { decision-making process to enhance their level of organizational commitment. }\end{array}$ \\
\hline $\begin{array}{l}\text { Email: } \\
\text { salahuaddin99@gmail.com }\end{array}$ & $\begin{array}{l}\text { Originality/value: The study presents evidence from a new setting where } \\
\text { insufficient analysis has been performed to investigate the direct relationship } \\
\text { between the variables tested. }\end{array}$ \\
\hline
\end{tabular}

\section{Introduction}

Rapid changes occur around the globe nearly every day, and the business market is getting more competitive. Hence organizations are to take great strategies to sustain in the marketplace. Most organizations have realized the significance of involving their employees in every work activity and allowing their participation in decision-making to remain active and committed (Scott-Ladd \& Marshall, 2004). Employees are known as a source of idea generation, and they are the backbone of any organization (Halawi \& Haydar, 2018). Therefore, workers have a tremendous need to participate and engage in organizations' decision-making process. In addition, management should take their views and voices into account (Constantin \& Baias, 2015). If the workers dedicate themselves to their companies, they do much more than if they are not.

Participative decision-making is considered a special form of delegation where employees 
participate in making decisions and choices that bridge the gap of communication between the management and workers. Participative decision-making is the same as employee involvement, in which employees gain autonomy to be involved in organizational activities such as planning and directing, which leads them to be committed and productive (Noah, 2008).

In many organizations, the decision-making task is undertaken by top management teams without the participation of lower-level managers and implementing such decisions taken by senior management sometimes becomes difficult, especially when those decisions are not favorable to the staff who are the implementers (Dede, C. H. 2019). Somech (2002) argues that decentralized authority structures have the potential to achieve results than the traditional topdown bureaucratic structures.

One of the most critical aspects of every organization's success or failure is the mobilization and focusing of people's power to achieve the organization's goals. The importance of employee participation practice is essential for the growth of organizations. It guarantees that employees are willing to engage in organizationally appropriate professional decision-making and market planning methods that are appropriate for their position within a corporation (Ekerman, 2006).

Previous research linked participative decision-making with organizational performance, employee performance and Job satisfaction(Saputra et al., 2015; Princy \& Rebeka, 2019; Srinivasan, 2021; Dede, 2019); some other studies considered employee commitment as a mediator variable (Phipps et al., 2013; Han et al., 2010; Butali \& Njoroge, 2018). This study examined the direct influence of participative decision making on the individual aspects of organizational commitment as well as investigated the controlling role of the demographic measures (control variables). Many comparable experiments have been carried out in developed countries, with less evidence gained in developing countries. This research is being carried out in Yemen, where inadequate analysis has been carried out to explore the relationship between the factors investigated.

\section{Objectives of the Study}

\section{General objective:}

To investigate the relationship between participative decision making and organizational commitment among employees working in the mobile telecom companies in Yemen.

\section{Specific Objectives:}

1. To determine the relationship between participative decision-making and affective commitment.

2. To explore the relationship between participative decision-making and continuance commitment.

3. To assess the relationship between participative decision-making and normative commitment.

\section{Research Hypotheses}

Copyright (C) 2020, Journal of Advanced Research in Economics and Administrative Sciences (JAREAS), Under a 
$\mathrm{H}$ 1: A significant positive relationship exists between participative decision-making and affective commitment.

H 2: A significant positive relationship exists between participative decision-making and continuance commitment.

H 3: A significant positive relationship exists between participative decision-making and normative commitment.

\section{Pilot Study}

A pilot study has been conducted among 30 employees, and the results indicated that the questionnaire items are reliable. The following figure represents the results of Cronbach's Alpha test.

Table 1: Reliability Statistics

\begin{tabular}{llll}
\hline Construct & Cronbach's Alpha & Number of Items & Remark \\
\hline $\begin{array}{l}\text { Participative Decision } \\
\text { Making }\end{array}$ & 0.850 & 4 & Good \\
$\begin{array}{l}\text { Organizational } \\
\text { Commitment }\end{array}$ & 0.915 & 13 & Excellent \\
\hline
\end{tabular}

Source: Author

\section{Conceptual Framework of the Study}

Independent Variable Dependent Variables

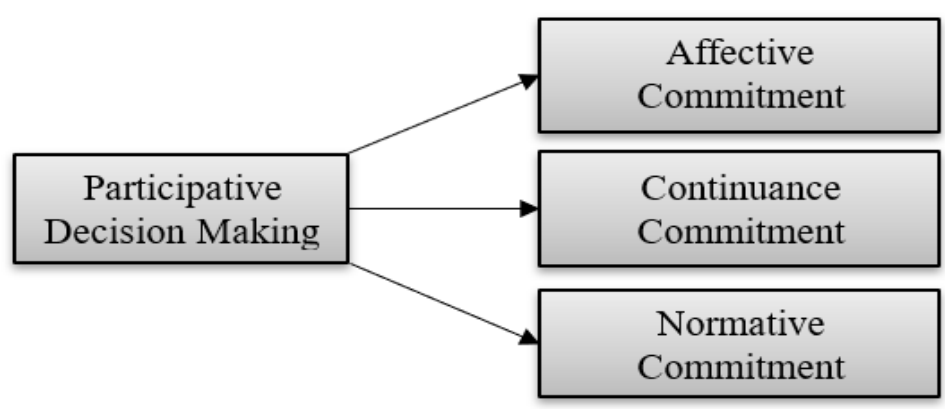

Figure 1: Conceptual framework of the Study

\section{Literature Review}

\section{Theoretical Review}

\section{Participative Decision-Making}

Participative decision-making refers to the process of involving, empowering and encouraging employees to give inputs towards value creation and organizational performance improvement (Sofijanova \& Chatleska, 2013). Westhuizen (2010) also defines employee participation as the 
direct and indirect involvement of employees either individually or as groups and their contribution to the decision-making process.

Employee participation is commonly characterized as a process through which authority is exchanged between individuals who are otherwise hierarchically separated (Locke \& Schweiger, 1979; Wagner, 1994). Staff involvement in decision-making balances supervisors' participation in information collecting, decision-making, as well as problem-solving activities by their subordinates (Wagner, 1994).

For effective implementation of management strategies, employee's participation takes a vital role (Harber\&Marriot, 1991). The participation of employees is a behavioural and emotional repetition that helps fulfil human and corporate objectives (Higgins, 1982). For example, According to Appelbaum et al. (2000), the opportunity to actively participate in policymaking fosters trust between employees and their managers, increasing employee engagement and motivation.

\section{Organizational Commitment}

Organizational commitment is defined by Porter (1990) as the continued tendency of staff to take on or engage in unique organizational activities. It is a product of employee trust and fear of losing their current positions if they have demonstrated no contribution to their job. As Rebecca (2013) adds, organizational commitment is seen as not just binding workers to their organizations' goals and priorities but also having a sense of value and an understanding of those objectives, encouraging them to make a significant effort on behalf of the company to uphold and protect their dedication. The accomplishment of corporate goals and the execution of the work within a limited period and with minimal expenses can be done by empowerment and involvement in decision-making. It motivates employees to strive harder or to measure more thoroughly. However, their findings showed that workers employed in a given organization could obtain more experience and skills to perform the requisite work. They thus foster their efficiency and operational effectiveness (Salleh et al., 2013; Yeh et al., 2012).

\section{Types of Organizational Commitment}

According to Annakili, P. and Jayam, R (2018), organizational commitment is seen in the following different forms:

Affective or moral commitment happens as workers actively accept the aims and principles of the company and take responsibility for the organization's performance. They thus typically demonstrate a high degree of achievement, optimistic attitudes to work and a readiness to continue in the company.

Continuance Commitment occurs when employees stay in the organization because they get a return and rewards for their efforts. When their rewards match their expectations, they tend to pay more effort. They also demonstrate devotion since they are frightened of losing their jobs if they quit the organization.

Copyright (C) 2020, Journal of Advanced Research in Economics and Administrative Sciences (JAREAS), Under a 
Normative commitment is connected with standards of behavior and social norms. The attitudes of employees under this pattern are similar, like those having affective commitment.

\section{Empirical Review}

Previous research has shown that participation in decision-making and commitment are related (Louis and Smith, 1992). When employees are willing to participate in decision-making, they perceive it as a boost for their working group's performance (Kukenberger et al., 2015). Business analysis in Malaysia revealed that management stresses their subordinate participation in decision-making (Matt, 2007). Menderson (2009) has pointed out that this dedication gives staff ample respect and increases workplace satisfaction. In this sense, it was said that workers' participation in decision-making would enhance their job satisfaction and thus theoretically stimulate teachers' work. Mwangi (2011) also stated that delegation decision-making contributed to improved productivity and motivation.

Widanto \& Satrya (2019) investigated the influence of participation in decision-making and psychological ownership on organizational commitment, which leads to employee knowledge sharing. The study had 153 respondents from various sectors. The study's findings indicated that participatory decision making will increase employee commitment through the use of psychological ownership. However, the findings revealed no effect on knowledge sharing behavior.

Saputra et al. (2015) in their study, revealed that participative decision making has a significant and positive impact on the job performance of the University of Utara Malaysia. The study recommended that the management of the university recognize the diversity of their staff and implement a practice to increase the level of job performance and keep them motivated. The study argued that employee participation is a key factor for increasing the job performance of the university academic staff.

Phipps et al. (2013) investigated the relationship between employee involvement and organizational productivity, considering organizational commitment as a moderator in this relationship. According to the study, both involvement as well as commitment go hand in hand in influencing organizational productivity.

Elele \& Fields (2010) investigated the link between decision-making involvement and organizational commitment among Nigerian and American employees working in the public sector. Employee actual and desired participation are related to affective and normative commitment but not to continuance commitment among Nigerian workers. Only actual vs desired levels of participation were positively associated to affective and normative organizational commitment among American employees. Actual levels of participation, on the other hand, were negatively associated with continuance commitment.

In his research, Singh (2009) claimed that due to competitive pressures and quickly changing market circumstances, firms must adopt flexible, adaptable, and lucrative strategies in today's complicated working environment and fierce competition. Furthermore, businesses recognize

Copyright (C) 2020, Journal of Advanced Research in Economics and Administrative Sciences (JAREAS), Under a 
that their workers are their most valuable asset, and the company's performance is dependent on employees' increased engagement in the generation of new ideas. Employee engagement may help businesses find inspiration, develop working habits, and make better decisions at work in various ways.

Bhatti, K. K., \& Qureshi, T. M. (2007) Argued that the engagement of workers has a positive impact on employee satisfaction, commitment and productivity. According to the report, rising employee engagement is a long-term mechanism that requires commitment to both management and employee initiative.

\section{Methodology and Procedures}

\section{Research Design}

To examine the link between participative decision and organizational commitment, a descriptive-analytical design was adopted.

\section{Population}

The employees of the four mobile phone companies' main branches in the capital city of Yemen (Sana'a), namely: Yemen Mobile, Sabafon, MTN Yemen, and Y-Telecom.

\section{Sample Size and Sampling Technique}

The researcher applied a simple random sampling technique in which 30 employees from each company were selected randomly, establishing 120 respondents from the headquarters of the four companies in the capital city of Yemen. This technique gives an equal chance for every unit in the population to be selected and represented. It helps in avoiding sampling bias.

\section{Tools for Data Collection}

Primary as well as secondary data were employed in this study. A survey was used to collect primary data, while extensive desk analysis was used to obtain secondary data. The primary data was collected using a questionnaire survey adapted from Tabouli, E. M., Habtoor, N. A., and Nashief, M. (2016) and Abdullah (2011). The independent variable is 'participative decisionmaking'. On the other hand, the dependent variable is organizational commitment, which was measured in terms of affective, continuance, and normative commitment. The questionnaire begins with demographic information and is then followed by two parts that reflect participative decision making as the independent variable and organizational commitment as the dependent variable. The questionnaire contains seventeen (17) items in total. A total of 120 questionnaires were valid for the data analysis. A five-point Likert scale ranges from Strongly Agree to Strongly Disagree was adopted. Regression and correlation analysis were used to evaluate the three hypotheses.

\section{Results and Discussion}

\section{Demographic Characteristics of Participants}

Copyright (C) 2020, Journal of Advanced Research in Economics and Administrative Sciences (JAREAS), Under a 
Table 2: Gender of respondents

\begin{tabular}{ccc}
\hline Gender & Frequency & Percentage \\
\hline Male & 108 & 90 \\
Female & 12 & 10 \\
\hline Total & $\mathbf{1 2 0}$ & $\mathbf{1 0 0}$
\end{tabular}

Source: Authors

The results of the study in the table above show that out of 120 respondents, 90 employees are males, representing 90\%, and 12 employees are female, representing only $10 \%$. Hence the majority of the respondents are males. The number of male staff working in the mobile telecom companies is much higher than the number of women staff due to the nature of the telecom industry in the country.

Table 3: Age distribution of respondents

\begin{tabular}{lll}
\hline Age & Frequency & Percentage \\
\hline From 31-40 & 102 & 85 \\
From 41- 50 & 18 & 15 \\
\hline Total & $\mathbf{1 2 0}$ & $\mathbf{1 0 0}$ \\
\hline
\end{tabular}

Source: Authors

The table above shows that out of 120 respondents, 102 employees, representing $85 \%$, were between 31- 40 years old, and 15 respondents representing 15\%, were between 41-50 years old. This indicates that most of the employees are below 40 and above 30 years old.

Table 4: Education level of respondents

\begin{tabular}{lll}
\hline Education & Frequency & Percentage \\
\hline Bachelor degree & 54 & 45 \\
Master & 60 & 50 \\
Doctorate & 6 & 5 \\
\hline Total & $\mathbf{1 2 0}$ & $\mathbf{1 0 0}$
\end{tabular}

The research data indicates that out of 120 respondents, 54 employees representing $45 \%$ have a bachelor's degree, 60 employees representing 50\% have a master's degree, six employees representing $5 \%$ have a doctorate. Hence, most of the employees are master's degree holders, which indicates that employees of the telecom companies in Yemen possess higher qualifications.

Table 5: Years of Experience of respondents

\begin{tabular}{lll}
\hline Experience & Frequency & Percentage \\
\hline Less than five years & 6 & 5 \\
From 5 to 10 years & 36 & 30 \\
From 11 to 15 years & 48 & 40 \\
From 16 to 20 years & 30 & 25 \\
\hline Total & $\mathbf{1 2 0}$ & $\mathbf{1 0 0}$ \\
\hline
\end{tabular}

Source: Authors

Copyright (C) 2020, Journal of Advanced Research in Economics and Administrative Sciences (JAREAS), Under a Creative Commons Attribution 4.0 International License 
In this study, out of 120 respondents, 6 of them representing 5\%, has less than five years of work experience, 36 employees representing 30\% have 5-10 years of experience, 48 employees representing $40 \%$ have 11-15 year experience, 30 employees representing $25 \%$ have 16-20 year experience. Hence the majority of the employees having 11- 15 years of work experience.

\section{Descriptive Statistics}

The study's hypotheses were evaluated using a variety of statistical approaches. Correlation analysis was used to examine the relationship between variables. The hypotheses were evaluated using regression analysis. The means, standard deviations, and correlations for the independent and dependent variables are shown in the following table.

Table 6: Mean, standard deviations and correlations between variables

\begin{tabular}{|c|c|c|c|c|c|}
\hline Variables & $\begin{array}{l}\text { Mean } \\
\pm \mathrm{SD}\end{array}$ & $\begin{array}{l}\text { Employees } \\
\text { Participation }\end{array}$ & $\begin{array}{l}\text { Affective } \\
\text { commitment }\end{array}$ & $\begin{array}{l}\text { Continuance } \\
\text { commitment }\end{array}$ & $\begin{array}{l}\text { Normative } \\
\text { commitment }\end{array}$ \\
\hline $\begin{array}{l}\text { Participative } \\
\text { Decision making }\end{array}$ & $\begin{array}{l}3.413 \\
\pm \\
0.708\end{array}$ & & & & \\
\hline $\begin{array}{l}\text { Affective } \\
\text { commitment }\end{array}$ & $\begin{array}{l}4.040 \\
\pm \\
0.713\end{array}$ & $.483^{* *}$ & & & \\
\hline $\begin{array}{l}\text { Continuance } \\
\text { commitment }\end{array}$ & $\begin{array}{l}3.838 \\
\pm \\
0.764\end{array}$ & $.599^{* *}$ & $.848^{* * *}$ & & \\
\hline $\begin{array}{l}\text { Normative } \\
\text { commitment }\end{array}$ & $\begin{array}{l}3.688 \\
\pm \\
0.693\end{array}$ & $.724^{* *}$ & $.768^{* * *}$ & $.704^{* *}$ & \\
\hline Gender & - & $-.373^{* *}$ & $.263^{*}$ & 0.126 & -0.091 \\
\hline Age & - & 0.002 & 0.134 & -0.002 & 0.140 \\
\hline Qualification & - & 0.209 & -0.062 & 0.203 & 0.137 \\
\hline Experience & - & -0.126 & 0.010 & -0.038 & $-.229^{*}$ \\
\hline \multicolumn{6}{|c|}{$* * \mathrm{p}<0.01, * \mathrm{p}<0.05$} \\
\hline \multicolumn{6}{|c|}{$\begin{array}{l}\text { The table displays the hypothesized relationship between the variables. The three elements of } \\
\text { organizational commitment were positively correlated with one another. These components are } \\
\text { also related positively to participative decision-making, suggesting that the higher the degree of } \\
\text { employee participation in decision-making, the greater their commitment to the organization. } \\
\text { Among the demographic measures, the age and educational qualification of the respondents } \\
\text { were not correlated with participative decision-making and all the aspects of organizational } \\
\text { commitment. However, gender and work experience had a significant, although negative, } \\
\text { correlation with participative decision-making and normative commitment, indicating that the } \\
\text { higher the work experience, and the lower is the responsibility or obligation of the employees } \\
\text { towards the organization. }\end{array}$} \\
\hline
\end{tabular}

Copyright (C) 2020, Journal of Advanced Research in Economics and Administrative Sciences (JAREAS), Under a 
The above correlations permit analysis of the effect of participative decision-making on the individual aspects of organizational commitment while controlling the demographic measures (control variables).

Table 7: Model summary and coefficients for the impact of participative decision-making on affective commitment

\begin{tabular}{|c|c|c|c|c|c|}
\hline \multirow{4}{*}{$\begin{array}{l}\text { Participativedecision } \\
\text { making } \\
\text { Affective } \\
\text { commitment }\end{array}$} & \multicolumn{2}{|c|}{$\begin{array}{l}\text { Unstandardized } \\
\text { Coefficients }\end{array}$} & \multirow{2}{*}{$\begin{array}{l}\text { Standardized } \\
\text { Coefficients } \\
\text { Beta } \\
\end{array}$} & \multirow[t]{2}{*}{$\mathbf{t}$} & \multirow[t]{2}{*}{ p-value } \\
\hline & $\mathbf{B}$ & SE & & & \\
\hline & 2.380 & 0.348 & & 6.842 & 0.000 \\
\hline & 0.486 & 0.100 & 0.483 & 4.872 & 0.000 \\
\hline \multicolumn{6}{|c|}{$\mathrm{R}^{2}=0.233, \mathrm{~F}(1,78)=23.239 * * *$} \\
\hline \multicolumn{6}{|l|}{$\begin{array}{l}p^{* * *}<0.001 \\
\text { Source: Authors }\end{array}$} \\
\hline \multicolumn{6}{|c|}{$\begin{array}{l}\text { The regression analysis in Table above shows the percent of the variance in the dependent } \\
\text { variable (affective commitment) expressed by the independent variable (participative decision } \\
\text { making), (analysis of } \mathrm{R}^{2} \text { ). The findings reveal that the participative decision making was } \\
\text { significant }\left(\mathrm{F}[1,78]=23.739, \mathrm{p}<0.001 \text { ) with } \mathrm{R}^{2} \text { value of } 0.233 \text {, which shows that } 23.3 \% \text { of the }\right. \\
\text { corresponding variation in active commitment can be accounted by a change in the level of } \\
\text { participative decision making. Further, the significance of regression analysis tested using the } \\
\text { regression coefficients }(\beta) \text { shows that a significant relationship between participative decision } \\
\text { making and affective commitment exists ( } \beta=0.48, p<0.001 \text { ), thereby confirming hypothesis } 1 \text {. } \\
\text { The results of the current study are consistent with the findings of Kumar and Saha (2017), in } \\
\text { which participation in decision-making is a determinant of job satisfaction and affective } \\
\text { commitment. While the greater the flexibility provided to employees to have a say in } \\
\text { organizational decisions, the greater the affective commitment they demonstrate. }\end{array}$} \\
\hline
\end{tabular}

Table 8: Model summary and coefficients for the impact of participative decision-making on continuance commitment

\begin{tabular}{llllll}
\hline & \multicolumn{1}{c}{$\begin{array}{l}\text { Unstandardized } \\
\text { Coefficients }\end{array}$} & & \multicolumn{1}{c}{$\begin{array}{l}\text { Standardized } \\
\text { Coefficients }\end{array}$} & & \\
\cline { 2 - 5 } & $\mathbf{B}$ & SE & Beta & p-value \\
\cline { 2 - 5 } $\begin{array}{l}\text { Participativedecision } \\
\text { making }\end{array}$ & 1.632 & 0.341 & & 4.729 & 0.000 \\
$\begin{array}{l}\text { Continuance } \\
\text { commitment }\end{array}$ & 0.646 & 0.098 & 0.599 & 6.605 & 0.000 \\
\hline $\mathrm{R}^{2}=0.359 \mathrm{~F}(1,78)=43.630 * * *$ & & & & \\
\hline$p^{* * *<0.001}$ & & & & &
\end{tabular}

Source: Authors

Copyright (C) 2020, Journal of Advanced Research in Economics and Administrative Sciences (JAREAS), Under a Creative Commons Attribution 4.0 International License 
Similarly, the findings in table above reveal that the participative decision making was significant for continuance commitment $(\mathrm{F}[1,78]=43.630, \mathrm{p}<0.001)$ with $\mathrm{R}^{2}$ value of 0.359 , which shows that $35.9 \%$ of the corresponding variation in continuance commitment can be accounted by a change in the level of participative decision making. Further, the significance of regression coefficients shows a significant relationship between participative decision making and continuance commitment $(\beta=0.59, \mathrm{p}<0.001)$, thereby proving hypothesis 2 . The analysis results also correspond to the Bhatti, K. Et Al. research (2011), which demonstrated direct participation in the continuous organizational commitment of workers in the banking industry in Pakistan as a significant positive relationship.

Table 9: Model summary and coefficients for the impact of participative decision-making on normative commitment

\begin{tabular}{llllll}
\hline & \multicolumn{1}{l}{$\begin{array}{l}\text { Unstandardized } \\
\text { Coefficients }\end{array}$} & & $\begin{array}{l}\text { Standardized } \\
\text { Coefficients }\end{array}$ & t & p-value \\
& B & SE & Beta & \\
\cline { 2 - 6 } $\begin{array}{l}\text { Participative decision } \\
\text { making }\end{array}$ & 1.272 & 0.266 & & 4.773 & 0.000 \\
$\begin{array}{l}\text { Normative } \\
\text { commitment }\end{array}$ & 0.708 & 0.076 & 0.724 & 9.261 & 0.000 \\
\hline $\begin{array}{l}\mathrm{R}^{2}=0.524, \mathrm{~F}(1,78)=85.760 * * * \\
p^{* * *<0.001}\end{array}$ & & & & \\
\hline
\end{tabular}

Source: Authors

Further, the regression analysis in table 9 shows that the percentage of the variance in the dependent variable (normative commitment) is expressed by the independent variable. The findings reveal that the participative decision making was significant $(\mathrm{F}(1,78)=85.760$, $\mathrm{p}<$ 0.001 ) with $\mathrm{R}^{2}$ value of 0.524 , which shows that $52.4 \%$ of the corresponding variation in normative commitment can be accounted by a change in the level of participative decision making. Further, the significance of regression analysis tested using the regression coefficients shows a significant relationship between participative decision-making and normative commitment ( $\beta=0.72, p<0.001)$, thereby proving hypothesis 3 . The study also conforms to the Bhatti, K study et al. (2011) indicating a significant positive relationship between participative decision making and normative organizational commitment of banking sector personnel in Pakistan.

As the participation of employees in the process of decision-making is still a debatable topic in the organizational context, identifying its potential effect on the employees' commitment towards the organization is essential. The present study made an attempt to address this concern, and the findings reveal that the positive impact of employees' participation in all three aspects of organizational commitment, indicating that the increasing involvement of the employees in

Copyright (C) 2020, Journal of Advanced Research in Economics and Administrative Sciences (JAREAS), Under a 
decision making can increase their commitment and sustainability towards the organization. The result is also in accordance with the observation that the employees' involvement also increases their influence within the organization (Ohana et al., 2013; Farooq et al., 2019). The present findings indicate that employees' perspectives should be taken into consideration for organizational decisions, thereby leading to improved performance by employees.

\section{Theoretical Implications}

There are a few similar studies conducted in countries other than Yemen, and most of those studies linked participative decision-making with organizational performance, employee performance and Job satisfaction(Saputra et al., 2015; Princy \& Rebeka, 2019; Srinivasan, 2021; Dede, 2019); some other studies used employee commitment as a mediator variable (Phipps et al., 2013; Han et al., 2010; Butali \& Njoroge, 2018). Inside Yemen, and as per the researcher knowledge, no previous study has been conducted to test the same variables. The researchers thus assume that the present study theoretically contributes to the body of knowledge by presenting data from a different market context and examining the influence of participative decision making on the individual aspects of organizational commitment as well as investigating the controlling role of the demographic measures (control variables).

\section{Managerial Implications}

This study has several implications for managers. Firstly, managers should involve the employees in the decision-making process to obtain their commitment towards the organization's goals and end objectives and for accomplishing the tasks in the given time and with minimal cost. Secondly, employees should take part in the organization's decisions because they will implement such decisions and strategies, and the more they are involved, the more efficient they would perform.

\section{Conclusion and Suggestion}

The study investigated the relationship between participative decision-making and organizational commitment among employees of the mobile Telecom companies in Yemen. The results of the study indicated a significant relationship between participative decision-making and the three patterns of organizational commitment (affective, continuance, as well, as normative commitment). Hence, a change in the level of participative decision-making causes a variation in the level of commitment. Normative commitment receives the highest variation among others. The study also revealed that the longer the years of experience of employees, the lesser commitment they show towards their organizations. It can indicate that employees at the time of joining the organization feel committed and loyal towards their organizations, but within the time, they gradually lose interest and obligations towards their jobs. Accordingly, they should be encouraged and involved more in the decision-making process. As a result, the study suggests that management enhance staff empowerment and involvement in decision-making processes in order to promote organizational commitment.

Copyright (C) 2020, Journal of Advanced Research in Economics and Administrative Sciences (JAREAS), Under a 


\section{Conflict of Interest}

The authors of the article declare no conflict of interest.

\section{Funding}

This research study was not funded by any institution. The authors conducted the study on their own expenses.

\section{References:}

Abdullah, A. (2011). Evaluation of Allen and Meyers Organizational Commitment Scale: A Cross-Cultural Application in Pakistan. Journal of Education and Vocational Research, 1(3), 80-86. https://doi.org/10.22610/jevr.v1i3.13

Annakili, P., \& Jayam, R. (2018). How to increase organizational commitment through employees participation. Eurasian Journal of Analytical Chemistry, 13, 18-22.

Appelbaum, E., Bailey, T., Berg, P., Kalleberg, A. L., and Bailey, T. A. (2000) Manufacturing advantage: Why high-performance work systems pay off. Cornell University Press.

Bhatti, K. and Nawab, S., Akbar A. (2011) 'Effect of Direct Participation on Organizational Commitment', International Journal of Business and Social Science, 2(9), 15-23.

Bhatti, K. K., and Qureshi, T. M. (2007) 'Impact of employee participation on job satisfaction, employee commitment and employee productivity', International review of business research papers,3(2),54-68.

Butali, P., \& Njoroge, D. (2018). Effect of Employee Participation on Organizational Performance with Organizational Commitment as a Moderator. International Journal of Scientific Research and Management, 06(06), 478-485. https://doi.org/10.18535/ijsrm/v6i6.el015

Constantin, E. C., \& Baias, C. C. (2015). Employee voice• key factor in internal communication. Procedia-Social and Behavioral Sciences, 191, 975-978.

Dede, C. H. (2019)'Employee Participation in Decision Making and Organizational Productivity: Case Study of Cross River State Board of Internal Revenue, Calabar', International Journal of Economics and Business Management, 5(1),84-93.

Ekerman, G. (2006), Job Enrichment and Staff Motivation: Human Resource Management, Maskew Miller Longman (Pvt), Cape Town, 83-191.

Elele, J., \& Fields, D. (2010). Participative decision making and organizational commitment: Comparing Nigerian and American employees. Cross Cultural Management An International Journal, 17(4), 368-392. https://doi.org/10.1108/13527601011086586

Farooq, O., Farooq, M., and Reynaud, E. (2019) 'Does Employees' Participation in Decision Making Increase the level of Corporate Social and Environmental Sustainability? An Investigation in South Asia', Sustainability, 11(2), 511.

Halawi, A., \& Haydar, N. (2018). Effects of Training on Employee Performance: A Case Study of Bonjus and Khatib \& Alami Companies. International Humanities Studies, 5(2), 2445.

Copyright (C) 2020, Journal of Advanced Research in Economics and Administrative Sciences (JAREAS), Under a Creative Commons Attribution 4.0 International License 
Han, T. S., Chiang, H. H., \& Chang, A. (2010). Employee participation in decision making, psychological ownership and knowledge sharing: Mediating role of organizational commitment in Taiwanese high-tech organizations. International Journal of Human Resource Management, 21(12), 2218-2233.

Harber, D., Marriott, F. and Idrus, N. (1991) Employee participation in TQC: the effect of job levels on participation and job satisfaction. International Journal of Quality \& Reliability Management, 8(5 ) 35-54.

Higgins, J. M. (1982). Human relations: Concepts and skills. McGraw-Hill College.

Kamau, S. W., and Chege, A. N. (2016) 'To Examine How Employee Participation in Decision Making Influences Organizational Commitment: A Case Study of Savannah Cement Limited',Management and Administrative Sciences Review, 5(5), 251-259.

Kumar, S. P. and Saha, S. (2017) 'Influence of Trust and Participation in Decision Making on Employee Attitudes in Indian Public Sector Undertakings', SAGE Open, 7(3), 1-13.

Ukenberger, M. R., Mathieu, J. E., and Ruddy, T. (2015) 'A cross-level test of empowerment and process influences on members' informal learning and team commitment', Journal of Management, 41(3), 987-1016.

Louis, K. S., \& Smith, B. (1992). Cultivating teacher engagement: Breaking the iron law of social class. Student engagement and achievement in American secondary schools', 119152.

Menderson, B. (2009). Employee Participation. Global Publishers.

Mwangi, C. (2011) Utilization of Employee Intelligence and Transformation Leadership for Employee Engagement in Public Universities. (MBA Thesis), Kenyatta University.

Noah, Y. (2008) 'A study of worker participation in management decision making within selected establishments in Lagos, Nigeria', Journal of social sciences, 17(1), 31-39

Ohana, M., Meyer, M., and Swaton, S. (2013) 'Decision-making in social enterprises: Exploring the link between employee participation and organizational commitment', Nonprofit and Voluntary Sector Quarterly, 42(6), 1092-1110.

Phipps, S. T. A., Prieto, L. C., \& Ndinguri, E. N. (2013). Understanding the impact of employee involvement on organizational productivity: The moderating role of organizational commitment. Journal of Organizational Culture, Communications and Conflict, 17(2), $107-120$.

Porter, M. (1990). The Competitive Advantage of Nations. The Free Press, A Division of McMillan, Inc., New York.

Qaisar, M., Safdar, R., And Sufyan, M. (2012)'Exploring Effect of Organizational Commitment on Employees' Performance. Interdisciplinary Journal of Contemporary Research in Business', 3(11), 248-255.

Rebecca, A., Stephen, G., Mahima, S., Howard, M., and Shelley, M. (2013) 'The Influence of Organizational Commitment and Individual Competence on Performance: In the Learning Organization Perspective',International Journal of Business and Behavioral Sciences, 3(8), 20-36.

Salleh, M., Amin, A., Muda, S., and Halim, M. A. S. A. (2013) 'Fairness of performance appraisal and organizational commitment' Asian Social Science,9(2), 121.

Copyright (C) 2020, Journal of Advanced Research in Economics and Administrative Sciences (JAREAS), Under a Creative Commons Attribution 4.0 International License 
Saputra, R. S., Akram, K., \& Perkasa, M. A. P. (2015). Impact of Participative Decision Making and Demographic Characteristics on Job Performance of University Academic Staff : Evidence from Universiti Utara Malaysia. Journal of Marketing and Consumer Research, 14, 29-39.

Scott-Ladd, B., \& Marshall, V. (2004). Article information :Participation in decision making: a matter of context? Leadership \& Organization Development Journal, 25(8), 646-662.

Singh, (2009) 'A Study on Employee Participation in Decision Making', Unitar E-Journal, 5(1), $20-38$.

Somech, A. (2002) 'Explicating the complexity of participative management: An investigation of multiple dimensions', Educational Administration Quarterly,38(3), 341-371.

Srinivasan, K. (2021). The Effect of Participative Decision Making on Job Satisfaction of the Employees of Manufacturing Companies in Coimbatore. Annals of R.S.C.B., 25(3), 2061-2077.

Tabouli, E. M., Habtoor, N. A., and Nashief, M. (2016) 'The impact of human resources management on employee performance: organizational commitment mediator variable'. Asian Social Science, 12(9), 176.

Wagner III, J. A. (1994) 'Participation's effects on performance and satisfaction: A reconsideration of research evidence', Academy of Management Review, 19(2), 312330.Saputra, R. S., Akram, K., \& Perkasa, M. A. P. (2015). Impact of Participative Decision Making and Demographic Characteristics on Job Performance of University Academic Staff : Evidence from Universiti Utara Malaysia. Journal of Marketing and Consumer Research, 14, 29-39.

Scott-Ladd, B., \& Marshall, V. (2004). Article information :Participation in decision making: a matter of context? Leadership \& Organization Development Journal, 25(8), 646-662.

Widanto, A., \& Satrya, A. (2019). The Role of Participative Decision Making and Psychological Ownership in Enhancing Organizational Commitment and Knowledge Sharing Behavior. The 1st Workshop on Multimedia Education, Learning, Assessment and Its Implementation in Game and Gamification in Conjunction with COMDEV 2018. https://doi.org/10.4108/eai.26-1-2019.2283200

Yeh, H., and Hong, D. (2012) 'The mediating effect of organizational commitment on leadership type and job performance', The Journal of Human Resource and Adult Learning, 8(2), 50.

Copyright (C) 2020, Journal of Advanced Research in Economics and Administrative Sciences (JAREAS), Under a Creative Commons Attribution 4.0 International License 